\title{
Erratum zu: Sepsis: Definitionen und Wirkungsweisen
}

\section{Erratum zu:}

Kapitel 8 in: H. Herwald, Infektionskrankheiten,

https://doi.org/10.1007/978-3-662-58519-1_8

Das Buch wurde unbeabsichtigterweise mit einer falschen Legende zu - Abbildung 8.2 publiziert. Die korrekte Legende lautet: Präsentation von phagozytierten bakteriellen Proteinfragmenten auf der Zelloberfläche. Das Kapitel wurde korrigiert. 